\title{
Supervised Recognition of Age-Related Spanish Temporal Phrases *
}

\author{
Sofia N. Galicia-Haro ${ }^{1}$ and Alexander F. Gelbukh ${ }^{2}$ \\ ${ }^{1}$ Facultad de Ciencias \\ Universidad Nacional Autónoma de México, Mexico, D. F. \\ sngh@fciencias.unam.mx \\ ${ }^{2}$ Centro de Investigación en Computación \\ Instituto Politécnico Nacional, Mexico, D. F. \\ gelbukh@gelbukh.com
}

\begin{abstract}
This paper reports research on temporal expressions shaped by a common temporal expression for a period of years modified by an adverb of time. From a Spanish corpus we found that some of those phrases are agerelated expressions. To determine automatically the temporal phrases with such meaning we analyzed a bigger sample obtained from the Internet. We analyzed these examples to define the relevant features to support a learning method. We present some preliminary results when a decision tree is applied.
\end{abstract}

Keywords: temporal expressions, learning supervised method, decision tree

\section{Introduction}

Some words or whole sequences of words in a text are temporal expressions: for example, today, Sunday 1st, two weeks, about a year and a half each refer to a certain period of time. Such words or sequences of words mainly share a noun or an adverb of time: today, week, year. This presents difficulties in automatically deciding whether a word or a sequence is a temporal expression. It is an important part of many natural language processing applications, such as question answering, machine translation, information retrieval, information extraction, text mining, etc., where robust handling of temporal expressions is necessary.

The Named Entity Recognition task of the Message Understanding Conferences considered the automatic recognition of expressions of time, whereby temporal entities were tagged as TIMEX. In [11] only "absolute" time expressions were tagged. They were categorized as three types: (1) date, complete or partial date expression, (2) time, complete or partial expression of time of day, and (3) duration, a measurement of time elapsed or a period of time during which something lasts. The absolute time expression must indicate a specific segment of time: for example, an expression of minutes must indicate a particular minute and hour, such as "20 minutes after ten",

* Work partially supported by the Mexican Government (CONACyT, SNI, CGPI-IPN, PIFIIPN). 
not "a few minutes after the hour," "a few minutes after ten," or "20 minutes after the hour". Determiners that introduced the expressions were not tagged. Words or phrases modifying the expressions (such as "around" or "about") were not tagged either.

Researchers have been developing temporal annotation schemes, for example [1] for English, where the authors produced a guideline intended to support a variety of applications. They were interested in the same temporal expressions: calendar dates, times of day, and durations. They broadened the annotation to introduce the specific values of the temporal expressions. For example, in the sentence: Police said the 31year-old Briton died Thursday, both 31-year-old and Thursday were marked as TIMEX, the first one with a value VAL="P31Y". Nevertheless they restricted the temporal expression recognition. Adverbs like meanwhile, still, before, etc. were not considered as part of the expressions, although they are temporal in their semantics, and are as a class less amenable to being pinned down to a timeline.

In this work, we analyzed other temporal expressions not considered in the previous works described. These phrases are recognized by an initial adverb: for example, around, still; and they end with a noun of time such as year, month. For example: aún en los setentas "still in the seventies", alrededor de año y medio "about a year and a half". We found that this type of phrase presents interesting cases. There is, for example, a group that describes a person's age. Automatic recognition of a person's age should be useful in question answering and machine translation tasks, inter alia. For example, consider the following sentence:

Aún a sus ocho años, Venus era muy confiada, diciendo que podía haber vencido a McEnroe. "Even at the age of eight years, Venus was very confident, saying he could have beaten McEnroe".

Spanish native speakers would understand that the phrase aún a sus 8 años denotes Venus's age. General machine translators, however, give the wrong phrases: 'yet his 8 years' or 'although his 8 years'. Also, this sentence would be retrieved by a question answering system to the specific question "How old was Venus?"

In this article, we present a corpus-based analysis carried out to determine the features for automatic determination. First, we present the characteristics of the temporal expressions modified by an adverb. Immediately after that, we present the automatic acquisition of the training examples. Then we present the analysis of the local context of the training examples. Finally we analyze the features required to develop a learning method and some preliminary results when a decision tree is applied.

\section{Temporal Expressions Modified by an Adverb}

Since the main job of adverbs is to modify verbs, adverbs include words that indicate the time in which the action of the verb takes place. These are some of the adverbs that are not based on adjectives. Adverbs of time (for example: now, then, tomorrow) create cohesion and coherence by forming time continuity in the events expressed in texts [9]. They are closely associated with narrative texts but they also appear in newspaper texts: for example, The players will report today, undergo physicals Wednesday, then go on the ice for the next three days. 
Works on temporal expressions have considered adverbs of time, for example [1, 12, 13]. But they chose adverbs with precise time meaning: for example, lately, hourly, daily, monthly, etc. We chose to analyze the Spanish temporal phrases that are modified by any adverb of time (AdvT) [7] placed at the beginning of the phrase followed by a noun of time (TimeN): for example, antes de 10 dias "before ten days", recién 10 años "lit. newly 10 years".

These phrases present interesting issues. For example, consider the following sentence:

A sus 80 años Juan tiene pulso de cirujano

We can modify the temporal expression a sus 80 años by an adverb. For example: Aún a sus 80 años Juan tiene pulso de cirujano; Hoy a sus 80 años Juan tiene pulso de cirujano; Últimamente a sus 80 años Juan tiene pulso de cirujano, etc. The sentences describe the same main fact: John, who is 80 years old, has surgeon's pulse. They tell us something else, however, when we introduce the modifier: aún "still" argues that in spite of his age he can have the firm pulse, hoy "today" concludes that today he has it, and últimamente "recently" suggests that in the recent past he has had a firm pulse. The adverbs make such conclusions obligatory and reinforce the meaning of time in different forms.

\subsection{Examples in Newspapers}

We obtained examples of these temporal expressions modified by an adverb of time from a text collection. The collection was compiled from a Mexican newspaper that is published daily on the Web almost in its entirety. The texts correspond to diverse sections, economy, politics, culture, sport, etc., from 1998 to 2002. The text collection has approximately 60 million words [2].

We wrote a program to extract the sentences matching the following pattern: AdvT-something-TimeN

Adverbs of time (AdvT) are a set of 51 elements: ${ }^{1}$ actualmente, adelante, ahora, alrededor, anoche, antaño, anteayer, anteriormente, antes, aún, ayer, constantemente, cuando, de antemano, dentro, dentro de poco, después, en seguida, enseguida, entonces, finalmente, hasta este momento, hogaño, hoy, inmediatamente, instantáneamente, jamás, luego, mañana, más tarde, más temprano, mientras, mientras tanto, momentáneamente, nunca, ocasionalmente, por horas, posteriormente, previamente, prontamente, pronto, recién, recientemente, siempre, simultáneamente, tarde, temprano, todavía, últimamente, una vez, ya.

Something corresponds to a sequence of up to six words ${ }^{2}$ without punctuation marks, verbs or conjunctions.

Noun of time (TimeN) corresponds to: año "year", mes "month", dia "day", hora "hour", minuto "minute", segundo "second".

The extracted sentences were analyzed in [3]. From a subset of those examples where the adverb corresponds to actualmente "at present', ahora "now', alrededor

${ }^{1}$ DRAE, Real Academia Española. (1995): Diccionario de la Real Academia Española, 21 edición (CD-ROM), Espasa, Calpe

${ }^{2}$ A larger quantity of words guarantees no relation between the AdvT and the TimeN. 
"around', aún "still', and the noun of time corresponds to año "year', we found some phrases expressing age of persons.

\subsection{Expressions Denoting Age of Persons}

Usually the age of persons is described by Spanish temporal expressions including the time nouns años "years" and meses "months" (for babies). They can be recognized in the following ways:

\begin{tabular}{c|c|c}
\hline String & Context & Example \\
\hline de edad "old" & Right context & $\begin{array}{c}\text { María tiene } 8 \text { años de edad } \\
\text { "Mary is 8 years old" }\end{array}$ \\
\hline number & delimited by commas & María, de 8 años, \\
\hline $\begin{array}{c}\text { la edad de, } \\
\text { "the age of" }\end{array}$ & Left context & María a la edad de 8 años \\
\hline $\begin{array}{c}\text { de edad de, } \\
\text { "the age of" }\end{array}$ & Left context & María de edad de 8 años \\
\hline
\end{tabular}

The first two cases were considered in [10], the remaining cases corresponding to syntactic variants. There are other temporal expressions, however, that describe the age of person: for example, ${ }^{3}$ aún a tus 15 años, "still at yours 15 years", ahora con casi 20 años, "today with almost 20 years". In the sentences, these temporal phrases could denote a point in the timeline of a person, a point in the timeline of the events related in the sentence or a point in a tangential timeline.

From the previous results we manually select some examples, each one representing what we consider to be a class: a different combination of an adverb and a preposition before the quantity of years. The five resulting classes correspond to aún a, aún con, actualmente de, alrededor de, ahora de.

\section{Automatic Acquisition of the Training Examples}

Since our newspaper text collection contains a subset of all possible temporal phrases expressing the age of persons we analyzed a method to obtain a more representative group of phrases. There are different possibilities for obtaining such variants, and we consider the following ones:

- To look in other text collections for sentences that fulfill the previous pattern

- To look for collocations of the nouns of time that we choose and to generate new phrases with the previous pattern

- To look for examples on the Internet.

The first possibility is time-consuming because it would mean individual text searching since huge text collections in Spanish are not available in entirety. As regards the second option, since collocations are syntactic units we should also

\footnotetext{
${ }^{3}$ The translations of the Spanish examples are literal.
} 
consider many combinations (adverb-adjective, adjective-noun, determinants, possessives, etc.). In addition, synonyms are frequently used, being determined by the context and applied with certain freedom.

On the other hand, the third option would allow us to find in less time phrases generated by native speakers including commoner collocations. Nevertheless, we know that search the Internet has problems, as [8] has already described, principally owing to the arbitrariness of the statistics of the search engines: for example, missing pages or copies. We also know that the search engines deliver different answers to repetitions of the same question. Although these problems are not so significant in this work, it is important that the results are classified in accordance with complex and unknown algorithms, so we cannot know what predispositions have been introduced. Despite these considerations, we decided to search the Internet on the grounds that we do not know how the results are classified.

The main idea of obtaining more examples from the Internet is based on obtaining a few examples from the newspaper texts (corresponding to the five above-mentioned classes), simplifying them (eliminating determinants, adjectives, etc.) and searching for variants by including Google's asterisk facility [4]. The whole procedure consists of the following steps:

\section{$\operatorname{SEARCH}(\mathrm{C})$}

For each phrase of type ADV-*-NounT or string-*-NounT in C

(1) Obtain 100 examples from the Internet
(1.1) $\mathrm{D}=$ \{examples excepting such instances where $*$ includes verbs or punctuation $\}$

(1.2) Print D

(2) Classify them according to such words retrieved by *

(3) For each group of phrases sharing words retrieved by *, assign a class $D_{i}$

(3.1) $\mathrm{F}=$ class Di

(3.2) $\operatorname{SEARCH}(\mathrm{F})$

UNTIL no new elements are obtained.

For example: for the phrase ahora a mis 25 años, the string when simplified becomes "ahora a años" and the search is "ahora a * años" using the Google search engine tool limited to the Spanish language where the asterisk substitutes for the eliminated words. Google returns hits where there is a string of words initiated by "ahora a", then a sequence of words, ending with "años".

The example for the whole procedure in Figure 1 is presented as follows:

SEARCH("ahora $a$ * años")

Step (1) 100 examples

... Sólo mírate de ahora a cinco años ...

Eso, viéndolo ahora a tantos años de distancia...

... Ahora a diez años de distancia volvemos a reflexionar...

ahora a mis 35 años tengo exactamente la psicología y el destino de mi heroína...

... al enfrentarnos ahora a los años finales de Carlos I y de Felipe II ...

... Situados ahora a 150 años de distancia del nacimiento de Wagner ...

$$
\text { ... }
$$


Table 1. Overall results for the examples obtained from the Internet

\begin{tabular}{|l|c|c|c|c|}
\hline Type of phrase & \# examples & $\begin{array}{c}\text { \% age- } \\
\text { related }\end{array}$ & $\begin{array}{c}\text { \# short } \\
\text { snippet }\end{array}$ & $\begin{array}{c}\text { \# no } \\
\text { age }\end{array}$ \\
\hline aún a sus NUM años & 293 & 96 & 7 & 5 \\
\hline aún hoy a sus NUM años & 38 & 92 & 2 & 1 \\
\hline aún a tus NUM años & 7 & 100 & 0 & 0 \\
\hline ahora a mis NUM años & 182 & 99 & 1 & 1 \\
\hline aún con mis pocos NUM años & 1 & 100 & 0 & 0 \\
\hline aún con mis cortos NUM años & 2 & 100 & 0 & 0 \\
\hline aún con sus escasos NUM años & 4 & 100 & 0 & 0 \\
\hline aún con tus casi NUM años & 1 & 100 & 0 & 0 \\
\hline aún con sus casi NUM años & 7 & 57 & 0 & 3 \\
\hline aún con sus NUM años & 109 & 86 & 0 & 15 \\
\hline ahora de NUM años & 352 & 86 & 6 & 45 \\
\hline de alrededor de NUM años & 353 & 44 & 4 & 194 \\
\hline actualmente con NUM años & 270 & 80 & 3 & 50 \\
\hline actualmente de NUM años & 28 & 36 & 7 & 11 \\
\hline actualmente de unos NUM años & 16 & 19 & 1 & 12 \\
\hline ahora con casi NUM años & 118 & 67 & 0 & 39 \\
\hline ahora con más de NUM años & 90 & 46 & 7 & 45 \\
\hline ahora a NUM años & 112 & 0.9 & 8 & 103 \\
\hline ahora a los NUM años & 132 & 36 & 2 & 82 \\
\hline alrededor de NUM años & 242 & 16 & 9 & 194 \\
\hline alrededor de los NUM años & 355 & 84 & 4 & 54 \\
\hline
\end{tabular}

Step (2) $\quad \mathrm{D}=\{$

ahora a tantos años,

ahora a cinco años,

Ahora a diez años,

ahora a mis 35 años,

ahora a los años,

ahora a 150 años ... \}

Step (3) For each one of the classes a new process is initiated

SEARCH("ahora a tantos * años")
SEARCH("ahora a mis * años")

...

The process is repeated several times until no new repeated phrases are obtained. At the end, the sequences of words are classified to obtain those appearing with greater frequency. Because of the simplicity of the method, some phrases not corresponding to the temporal phrases we are interested in are picked up: for example, Ahora a diferencia de años anteriores ... "Now in contrast to previous years". There is a manual identification at the end of the whole process that deletes this kind of phrase.

We manually selected 21 classes corresponding to age-related temporal phrases. They appear in the first column of Table 1, where NUM considers numbers represented by digits or letters. 
Table 2. Results of context analysis for the classes maintaining the age-related meaning

\begin{tabular}{|c|c|c|c|c|}
\hline & \multicolumn{2}{|c|}{ Age-related } & \multicolumn{2}{|c|}{ No age } \\
\hline & $\begin{array}{l}\text { Right } \\
\text { context }\end{array}$ & \begin{tabular}{|c|} 
Left \\
context
\end{tabular} & $\begin{array}{l}\text { Right } \\
\text { context }\end{array}$ & $\begin{array}{c}\text { Left } \\
\text { context }\end{array}$ \\
\hline aún a sus NUM años & $\begin{array}{l}\text { de vida (4) } \\
\text { de existencia } \\
\text { de edad (44) } \\
\text { cumplidos (4) } \\
\text { VERBS (148) } \\
\text { NAMES (6) } \\
\text { PUNCT (40) } \\
\end{array}$ & & $\begin{array}{l}\text { de antigüedad } \\
\text { de viajar } \\
\text { de experiencia } \\
\text { de tradición } \\
\text { de viuda }\end{array}$ & \\
\hline $\begin{array}{l}\text { aún hoy a sus NUM } \\
\text { años }\end{array}$ & $\begin{array}{l}\text { de edad (4) } \\
\text { VERBS (20) } \\
\text { PUNCT (11) }\end{array}$ & $\begin{array}{l}\text { CONJ (23) } \\
\text { PUNCT (9) }\end{array}$ & de partida & \\
\hline aún a tus NUM años & PUNCT (4) & & & \\
\hline $\begin{array}{l}\text { ahora a mis NUM } \\
\text { años }\end{array}$ & $\begin{array}{l}\text { de edad (11) } \\
\text { PUNCT (39) }\end{array}$ & $\begin{array}{l}\text { PUNCT (38) } \\
\text { CONJ (72) }\end{array}$ & de casada & \\
\hline $\begin{array}{l}\text { aún con sus escasos } \\
\text { NUM años }\end{array}$ & PUNCT (4) & & & \\
\hline ahora de NUM años & $\begin{array}{l}\text { *PUNCT (233) } \\
\text { de edad (26) }\end{array}$ & $\begin{array}{l}* \text { NAM/PN } \\
\text { PUNCT (233) } \\
\text { NAM/PN (18) }\end{array}$ & ahode list & $\begin{array}{l}\text { SER (27) } \\
\text { periodo } \\
\text { disponer (4) }\end{array}$ \\
\hline
\end{tabular}

\section{Analysis of the Training Examples}

We manually analyzed some examples for each one of the 21 obtained classes. We found that in some cases the meaning of the age-related temporal phrase was independent of the surrounding words. To determine automatically the meaning of these temporal phrases a more thorough analysis involving a larger sample is required.

For this purpose, we obtained examples by searching again on the Internet. The quantity of pages automatically obtained for each search was limited to 50, i.e. to obtain a maximum of 500 snippets. The overall results are presented in Table 1 . The first column corresponds to the 21 classes. The second column shows the quantity of examples obtained, after the elimination of phrases where there was no relation between the AdvT and the TimeN.

Since the examples were automatically obtained, some of them were not considered because of the lack of text presented in the snippet or because the phrase was missing in the snippet. Column 4 gives the number of the eliminated examples.

Columns 3 and 5 show the results after the general syntactic and semantic analysis of the context in each sentence for the recognition or otherwise of age-related meaning respectively.

We manually analyzed the local context in the examples. Table 2 summarizes the results for the cases in Table 1 with more than $85 \%$ of age-related phrases. The column "Age-related" comprises the right and left context for the phrases denoting 
age of person. Column "No age" comprises the right and left context for the phrases not denoting age of person. Table 3 summarizes the results for the cases in Table 1 with less than $85 \%$ of age-related phrases. The patterns appearing in the right and left context correspond to the more general and more interesting ones; for example, in the class aún a sus NUM años there are 34 phrases missing since they require many different patterns.

Table 3. Results of context analysis for the classes with age-related meaning based on context

\begin{tabular}{|c|c|c|c|c|}
\hline & \multicolumn{2}{|c|}{ Age-related } & \multicolumn{2}{|c|}{ No age } \\
\hline & $\begin{array}{c}\text { Right } \\
\text { context }\end{array}$ & $\begin{array}{c}\text { Left } \\
\text { context }\end{array}$ & $\begin{array}{c}\text { Right } \\
\text { context }\end{array}$ & $\begin{array}{c}\text { Left } \\
\text { context }\end{array}$ \\
\hline $\begin{array}{l}\text { aún con sus casi } \\
\text { NUM años }\end{array}$ & $\begin{array}{l}\text { VERB } \\
\text { PUNCT (2) } \\
\text { de edad }\end{array}$ & PUNCT & $\begin{array}{l}\text { en el mercado } \\
\text { de servicio } \\
\text { de vigencia }\end{array}$ & \\
\hline $\begin{array}{l}\text { aún con sus } \\
\text { NUM años }\end{array}$ & acsus list & PUNCT (15) & No_acsus list & \\
\hline $\begin{array}{l}\text { de alrededor de } \\
\text { NUM años }\end{array}$ & de edad (11) & $\begin{array}{l}\text { NM/PN PT (15) } \\
\text { NAM/PN (117) }\end{array}$ & Nordealde list & $\begin{array}{l}\text { Noldealde } \\
\text { list }\end{array}$ \\
\hline $\begin{array}{l}\text { actualmente con } \\
\text { NUM años }\end{array}$ & actcon_r list & actcon_l list & $\begin{array}{l}\text { No_actcon } \\
\text { list }\end{array}$ & \\
\hline $\begin{array}{l}\text { actualmente de } \\
\text { NUM años }\end{array}$ & de edad (5) & NAM/PN (5) & & \\
\hline $\begin{array}{l}\text { actualmente de } \\
\text { unos NUM años }\end{array}$ & $\begin{array}{l}\text { de edad } \\
\text { NAM/PN PUNCT }\end{array}$ & & & SER (12) \\
\hline $\begin{array}{l}\text { ahora con casi } \\
\text { NUM años }\end{array}$ & $\begin{array}{l}\text { PUNCT VERB (21) } \\
\text { VERB (34) }\end{array}$ & \begin{tabular}{|l} 
i \{CONJ, \\
PUNCT\} (30)
\end{tabular} & $\begin{array}{l}\text { i }\} \\
\text { Noahoccasi } \\
\text { list }\end{array}$ & $\begin{array}{l}\mathrm{de} \\
\text { abandono(2) }\end{array}$ \\
\hline $\begin{array}{l}\text { ahora con más } \\
\text { de NUM años }\end{array}$ & ahconmade list & & No_ahocmas & hasta (4) \\
\hline $\begin{array}{l}\text { ahora a NUM } \\
\text { años }\end{array}$ & de edad & & & \\
\hline $\begin{array}{l}\text { ahora a los } \\
\text { NUM años }\end{array}$ & $\begin{array}{l}\text { de edad } \\
\text { VERB (21) }\end{array}$ & porque (4) & $\begin{array}{l}\text { No_ahoalos } \\
\text { list }\end{array}$ & \\
\hline $\begin{array}{l}\text { alrededor de } \\
\text { NUM años }\end{array}$ & $\{<100\}$ de edad (4) & \begin{tabular}{|l|}
$\{<100\}$ TENER \\
$(28)$ \\
\end{tabular} & & \begin{tabular}{|l|} 
hace $(47)$ \\
durante $(8)$
\end{tabular} \\
\hline $\begin{array}{l}\text { alrededor de los } \\
\text { NUM años }\end{array}$ & de edad (51) & & $\{<100\}(22)$ & \\
\hline
\end{tabular}

In the tables: VERB means a verb related to the adverb, NAMES correspond to person's name, PUNCT comprises comma, parenthesis, semicolon, CONJ corresponds to conjunctions introducing new phrases, NAM/PN corresponds to name or personal noun, SER comprises "to be" conjugation, TENER and CONTAR the "to have" verb. An asterisk means that the left and right contexts are matched. $\{<100\}$ means NUM value lower than 100. $\{i\}$ means it excludes context for "No age" cases.

We can see that the classes aún a sus NUM años and ahora de NUM años are the best examples for context identification. The worst case is alrededor de los NUM años, where we notice that almost all phrases indicate an age but in a general form: 
for example, el consumo de frutas se da sobre todo alrededor de los 60 años "the fruit consumption is mostly seen about 60 years old".

The class ahora de NUM años shows an interesting property: many age-related examples have right and left context matching that includes punctuation, isolating the temporal phrase and giving a context independent meaning.

Contexts for phrases that are not age-related share prepositional phrases modifying the noun time: for example, 7 años de casada "married for seven years", 7 años de cárcel "seven years in jail".

Some of the lists indicated in both tables by italics are enumerated in the following paragraphs and the number of cases is shown in parentheses when it is greater than 1: ahode: de antigüedad, de becas, de cárcel, de casados, de duración, más (5)

acsus: PUNCT (42), VERBO (21), CONJ (3), encima (3), a cuestas (4), a las espaldas, cumplidos, de edad (14), de vida (5)

dealde: de antiguedad (15), de duración (2, de evolución, de fallecido, de gobierno (2), de investigación, de investigar, de matrimonio, de persecución, de políticas, de prisión (2), de reformas, de trabajo, luz (9)

No_dealde: una antigüedad (7), datan (19), después (11), distancia (5), duración (2), SER (17), experiencia (3), lapso (2), luego (4), vida media (2), edad media, período (22), vida (3), vida conyugal.

The analysis sheds light on the preservation of the meaning. We wrote a program to classify the results of the left and right contexts. The results are presented in Table 4 , where the examples for each class are separated into age-related examples and nonage-related examples.

Table 4. Results of context classification

\begin{tabular}{|c|c|c|c|c|}
\hline & \multicolumn{2}{|c|}{ Age-related } & \multicolumn{2}{|c|}{ No age } \\
\hline & RC & LC & RC & LC \\
\hline aún a sus NUM años & $88 \%$ & & $100 \%$ & \\
\hline aún hoy a sus NUM años & $35 \%$ & & $100 \%$ & \\
\hline aún a tus NUM años & $57 \%$ & & & \\
\hline ahora a mis NUM años & & $61 \%$ & $100 \%$ & \\
\hline aún con sus escasos NUM años & $100 \%$ & & & \\
\hline ahora de NUM años & $86 \%$ & & & $71 \%$ \\
\hline aún con sus casi NUM años & $100 \%$ & & $100 \%$ & \\
\hline aún con sus NUM años & $89 \%$ & & $100 \%$ & \\
\hline de alrededor de NUM años & & $85 \%$ & & $51 \%$ \\
\hline actualmente con NUM años & $48 \%$ & & $70 \%$ & \\
\hline actualmente de NUM años & $50 \%$ & & & \\
\hline actualmente de unos NUM años & $100 \%$ & & & $100 \%$ \\
\hline ahora con casi NUM años & $37 \%$ & & $74 \%$ & \\
\hline ahora con más de NUM años & $64 \%$ & & $100 \%$ & \\
\hline ahora a NUM años & $100 \%$ & & & \\
\hline ahora a los NUM años & $46 \%$ & & $18 \%$ & \\
\hline alrededor de NUM años & & $72 \%$ & & $28 \%$ \\
\hline alrededor de los NUM años & $17 \%$ & & $41 \%$ & \\
\hline
\end{tabular}


The percentages show the number of examples which have a specific context according to the local context analysis. RC means right context and LC means left context.

We found that most of the classes have enough patterns to enable their recognition as either age-related or non-age-related. The worst cases (aún a tus NUM años, actualmente de NUM años, ahora a los NUM años, alrededor de los NUM años) have patterns for 40 to $60 \%$ of examples. We therefore concluded that automatic recognition can be based on the features obtained from the analysis.

\section{Decision Tree as the Recognition Model}

For automatic determination of the meaning of the temporal expressions that we analyzed one approach is to develop a recognition model as a binary classifier. The classifier goes through a list of possible expressions, classifying them into two classes: age meaning and no-age meaning. These two classes correspond to the concept that our system must learn.

Among the various types of learning approaches, we chose supervised inductive learning. All training examples state to which class they are assigned. After seeing all training data, the learner selects a hypothesis, one that can reliably approximate the target concept. This hypothesis is formalized as a decision tree in the decision tree learning approach that we selected [6].

In the decision tree each internal node represents a test of one of the attributes of the training data examples and the node's branches are the different values of such attributes. The decision tree contains all the necessary tests on all attributes obtained from the examples. The first attribute tested is the one with the highest information gain. The other attributes are recursively obtained according to the information gain criterion which eliminates the attributes and the examples previously classified by them. We applied DTREG Software 4 in the implementation of the decision tree. DTREG has many settings but, always trying to find the simplest tree, we chose to calculate entropy and the setting considering a mix of frequency distribution in the data set and balanced misclassification for smoothing.

Training data in this work consist of the collection of temporal expressions presented in Table 1. A number of attributes have been selected to describe the examples. These attributes are naïve approximations of linguistic properties that we described in Tables 2 and 3, and may be summarized as follows:

- the part of speech of the left and right contexts

- the prepositional phrase selected by the time noun

- the entity names in the left and right contexts

- the punctuation sign in the left and right contexts

- specific words in context (ser, contar, encima, etc.)

- number of years.

\footnotetext{
${ }^{4}$ http://www.dtreg.com/.
} 
To obtain these attributes, context information was considered in this work as two words in a window surrounding the target phrase without grammatical relations of the whole sentence in an automatic form. We applied the system for automatic morphological analysis of Spanish [5] to assign parts of speech to the words of the context. We wrote a program to classify the examples according to the context, to obtain noun phrases and to eliminate temporal phrases not matching the pattern AdvT-something-TimeN.

We applied the decision tree in a sample taken from another Mexican newspaper. We search in this collection for the phrases shown in the first column of Table 4.

\begin{tabular}{l|c|c|c}
\hline Phrase & Total & Correct detected & Correct \\
\hline aún a *años & 100 & 10 & 11 \\
\hline ahora de * años & 100 & 39 & 41 \\
\hline ahora con casi *años & 6 & 0 & 0 \\
\hline actualmente de *años & 100 & 20 & 22 \\
\hline
\end{tabular}

Although the number of examples is small, we could observe that the analyzed context is very similar for these kinds of phrases since the precision is very near the 100 percent mark. Also, it should be noted that we used the Google search engine (www.google.com) for the Spanish language so the analyzed context in Tables 2 and 3 corresponds to examples where several dialectal variations of Spanish are considered.

In nearly every case one faulty phrase was omitted. Two errors correspond to the lack of full syntactic parsing since an adjective was not identified as part of the adverbial phrase and a verb was missing because of the introduction of a circunstancial complement. One error was owed to the entity name recognizer. It was introduced to the inability to recognize a personal noun.

These errors show that the lists of phrases corresponding to local context presented in Tables 2 and 3 should be the base for future work on lexical, morphological, syntactic, and semantic categories for these temporal expressions' structural description in order to obtain a robust system. Other work will comprise the analysis of the effect of new attributes like the relation between left and right contexts.

We have omitted in this work a learning method to recognize expressions not appearing in the search phase. A second phase will consider the annotation of plain texts with the decision tree to obtain similar patterns in context that could vary in modifiers such as determinants, adjectives, and numbers.

\section{Conclusions}

The variety in the structure of temporary expressions necessitates the analysis of different combinations of classes of words. We analyzed temporal expressions including the noun of time year that are modified by an adverb of time and the whole phrase expressing a person's age. 
We first presented a method to enrich the classes of temporal phrases when only a few examples are compiled. To obtain a more representative sample we compiled examples from the Internet for each class. We manually analyzed the context surrounding them to define the specific context for such expressions in order to identify them automatically. Specific context was obtained for nine of 21 classes.

The classification was carried out by a well-known machine learning algorithm known as a decision tree and based on direct attributes. We obtained remarkable results by applying the decision tree to just a few examples from 300 sentences.

The automatic identification of these phrases and their interpretation will directly benefit natural language processing tasks including: response to questions; visualization of events in lines of time; generation of phrases; translation, etc. For example, questions on age are very common in demographic and health questionnaires and, if the interviewees feel comfortable speaking in the usual form, a system with this automatic recognition of age-related temporal expressions could translate such expressions to data repositories.

\section{References}

1. Ferro, Lisa, Laurie Gerber, Inderjeet Mani, Beth Sundheim and George Wilson: TIDES 2003 Standard for the Annotation of Temporal Expressions, MITRE Corporation (2004)

2. Galicia-Haro, Sofía N.: Using Electronic Texts for an Annotated Corpus Building. In: 4th Mexican International Conference on Computer Science, ENC 2003, Mexico, (2003) 26-33

3. Galicia-Haro, Sofía N.: Spanish Temporal Expressions: Some Forms Reinforced by an Adverb. Lecture Notes in Computer Science, N 5317 Springer Verlag (2008), 193-203

4. Gelbukh, A. and I. A. Bolshakov: Internet, a true friend of translators: the Google wildcard operator. International Journal of Translation (2006) 18(1-2), 41-48

5. Gelbukh, A. and G. Sidorov: Approach to construction of automatic morphological analysis systems for inflective languages with little effort. In: Computational Linguistics and Intelligent Text Processing, Lecture Notes in Computer Science, N 2588, Springer-Verlag. (2003) 215-220

6. Han, Jiawei and Micheline Kamber: Data Mining: Concepts and Techniques. Morgan Kaufmann Publishers (2006)

7. Hernando Cuadrado, Luis Alberto: Gramática del adverbio en español. Ed. Dykinson, 2006.

8. Kilgarriff, A.: Googleology is Bad Science. Computational Linguistics (2007) 33, 147-151

9. Llido, D., Berlanga. R. and Aramburu, M.J.: Extracting temporal references to assign document event-time periods. Lecture Notes in Computer Science 2113 (2001) 62-71

10. Mandel, Mark and Christopher Walter.: Pautas para la anotación del Tiempo para Lenguas poco enseñadas (basado en los estándares de TIMEX2) Versión 1.0 Consorcio de Datos Lingüísticos (2006)

11. Named Entity Task Definition (v2.1), Appendix C: Proceedings of the Sixth Message Understanding Conference (MUC-6). Columbia, MD. (1995) 317-332

12. Saquete, E., and Martinez-Barco, P.: Grammar specification for the recognition of temporal expressions. In Proceedings of Machine Translation and multilingual applications in the new millennium. MT2000, Exeter, UK (2000) 21.1-21.7

13. Saquete, Estela, Patricio Martinez-Barco, Rafael Muñoz: Recognizing and tagging temporal expressions in Spanish. In Workshop on Annotation Standards for Temporal Information in Natural Language, LREC 2002 